\title{
On the distribution of energy and number of earthquakes in accordance with the focal depth
}

\author{
P. Hederviri (*)
}

Ricevuto il 30 Narzo 1964

\begin{abstract}
Sumarr. - An investigation is presented here concerning the distribution of eartliquake energy and number of shocks in accordance with the focal depth. The global distribution of these quantities according to the depth of hypocentres can be approached by an exponential curve between 0 and about $500 \mathrm{~km}$ under the Earth's surface.

Rissevito. - Viene presentato dall A., in questa nota. uno studio sulla distribuzione dellenergia dei terremoti e il numero di scosse nei confronti della profondita focale. La distribuzione nel mondo di queste quantità nei confronti della profondita ipocentrale, puo essere rappresentata da una curva esponenziale compresa fra lo 0 e i $500 \mathrm{~km}$ al disotto della superficie della terra.
\end{abstract}

Ritsema ( $\left.{ }^{1}\right)$ emphasized the importance of studies concerning the connection between strain- (or energy-)release and focal depth of earthquakes. In his quoted paper he mentioned that the strain-release depth diagram of the Sunda Are and the same diagram of the Earth as a whole show surprisingly similar characteristics in the period of 1904-1946.

This extraordinarily interesting recognision induced the author of the present paper to extend the investigations for a larger scale of time. Gutenberga and Richter $\left({ }^{2}, 3\right)$ published the magnitude-data of the greatest shocks between 1896 and 1904; on the other hand the data of all shocks of manitude 6,9 and over it are at our disposal from 1904 till about the middle of 1962, due partly to the common work of Gutenbere and Richter ( $\left.{ }^{4}\right)$ and partly to the Bulletin of the Seismological Society of America $\left(^{5}\right)$. Altogether we have the data of 1389 earthqualies occured between the beginning of 1896 and about the middle of 1962 . We calculated the energy-release instead of the strain-release.

(*) F.R.A.S. - Vice.President of International Innar Society. 


\begin{tabular}{|c|c|c|c|c|c|c|c|}
\hline$\infty$ & 190000 & -0000 & 00000 & 00000 & 00000 & 00000 & จัง \\
\hline $\begin{array}{l}\frac{19}{10} \\
15\end{array}$ & 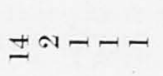 & 00000 & 00000 & 00000 & $0000-1$ & 00000 & ลิ \\
\hline$\stackrel{2}{n}$ & JaONO & 00000 & $00-00$ & 00000 & 00000 & 00000 & $\stackrel{\rho}{-1}$ \\
\hline$\stackrel{0}{i}$ & 010000 & $-10-0$ & 00000 & 00000 & 00000 & -0000 & is \\
\hline 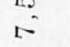 & $F r-\infty \in \infty$ & 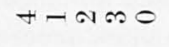 & 00000 & $00-00$ & 000100 & 00000 & 10 \\
\hline$\therefore$ & tod a & NOOOO & $000 \times 0$ & $00-00$ & 00000 & 00000 & 8 \\
\hline$\because$ & $\ddot{b}=\infty \times 0$ & NANOO & $0-0-1$ & 00000 & $-1-00$ & 00000 & $\stackrel{\infty}{\infty}$ \\
\hline â & $\varphi 0+\infty-$ & -NMO & 00000 & -ONO- & $00-\infty m$ & -0000 & : \\
\hline$\stackrel{?}{N}$ & $g \bar{s}^{\infty} \varrho+$ & $0-ー \infty$ & $0-000$ & $0000-1$ & $0-\infty-1$ & 00000 & ભิ \\
\hline$\vec{r}$ & $\infty \operatorname{lig}^{\infty} \infty 0.10$ & 小 & $0-0-0$ & n0000 & 000 No & 00000 & 刍 \\
\hline$\stackrel{0}{n}$ & 웜조 & $\forall \rightsquigarrow \infty \sim \infty \cdots$ & ONMNA & $0-0, a$ & $00-1-$ & to0 000 & 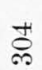 \\
\hline$\ddot{0}$ & ৪ัง & nam & $a-O a-$ & $000-0$ & $-0-\infty 0$ & Ho- -0 & $\stackrel{\infty}{\stackrel{\circ}{=}}$ \\
\hline$\underset{\Xi}{己} \Xi$ & 导吉灾节导 & 起急串志 & 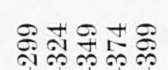 & 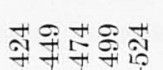 & 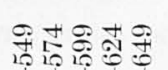 & 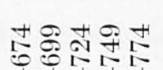 & 范 \\
\hline 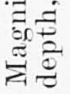 & 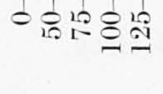 & 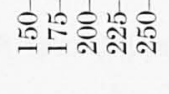 & 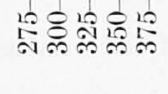 & 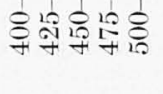 & 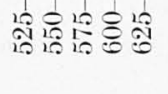 & 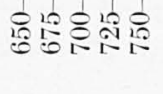 & 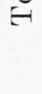 \\
\hline
\end{tabular}




\begin{tabular}{|c|c|c|c|c|c|c|c|}
\hline$\ddot{\infty}$ & n0000 & 00000 & 00000 & 00000 & 00000 & 00000 & $\infty$ \\
\hline$\infty$ & 00000 & 00000 & 00000 & 00000 & 00000 & 00000 & 0 \\
\hline$\infty$ & $0--n=$ & -0000 & 00000 & 00000 & 00000 & $0=000$ & 9 \\
\hline$\ddot{\infty}$ & $\infty \infty 0-0$ & -0000 & 00000 & 00000 & 00000 & 00000 & 9 \\
\hline$\infty$ & 00000 & 00000 & 00000 & 00000 & 00000 & 00000 & $\bullet$ \\
\hline$\infty$ & $\dddot{-}--0$ & 00000 & $00-00$ & $000=0$ & $0=0=0$ & $0=000$ & $\stackrel{0}{0}$ \\
\hline$\wp_{\infty}^{\infty}$ & gे+ー+0 & $0--00$ & $000=0$ & 00000 & 00000 & $0=000$ & 官 \\
\hline $\begin{array}{l}\text { नी } \\
\text { क }\end{array}$ & $n-000$ & 00000 & 00000 & 00000 & 00000 & 00000 & H \\
\hline$\stackrel{0}{\infty}$ & 00000 & 00000 & 00000 & 00000 & 00000 & 00000 & 0 \\
\hline$\vec{\infty}$ & $\widehat{ส} \leadsto N=0$ & $=--10$ & $=0=0$ & -0000 & $0=0=0$ & $0=000$ & ๙ \\
\hline$\dot{\infty}$ & $100=0$ & $0=00$ & $0=000$ & $-0=0$ & $0=000$ & $0=0=0$ & $\bullet$ \\
\hline$\theta$ & $\operatorname{gof}_{100} a-0$ & -1000 & $00-10$ & 00000 & o-0 & $-0=00$ & 5 \\
\hline$\stackrel{巳 巳 \Xi}{\Xi}$ & 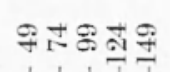 & 志岛㫄志 & 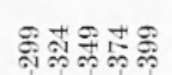 & 苟导弆路落 & 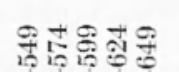 & 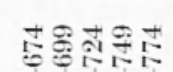 & $\ddot{ت}$ \\
\hline 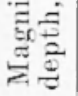 & 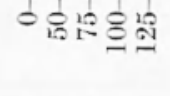 & 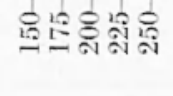 & 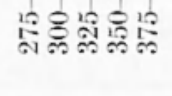 & 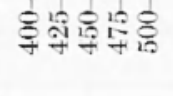 & 솜은돈영 & ํㅗㅇำ & $F$ \\
\hline
\end{tabular}


Table III.

\begin{tabular}{|c|c|c|c|}
\hline Depth, km & Number of shocks & Depth, $\mathrm{km}$ & Number of shocks \\
\hline $\begin{array}{r}0-49 \\
50-74 \\
75-99 \\
100-124 \\
125-149\end{array}$ & $\begin{array}{r}790 \\
181 \\
73 \\
94 \\
30\end{array}$ & $\begin{array}{l}400-424 \\
425-449 \\
450-474 \\
475-499 \\
500-524\end{array}$ & $\begin{array}{l}6 \\
1 \\
4 \\
2 \\
4\end{array}$ \\
\hline $\begin{array}{l}150-174 \\
175-199 \\
200-224 \\
225-249 \\
250-274\end{array}$ & $\begin{array}{l}43 \\
18 \\
37 \\
11 \\
13\end{array}$ & $\begin{array}{l}525-549 \\
550-574 \\
575-599 \\
600-624 \\
625-649\end{array}$ & $\begin{array}{r}2 \\
3 \\
6 \\
26 \\
6\end{array}$ \\
\hline $\begin{array}{l}275-299 \\
300-324 \\
325-349 \\
350-374 \\
375-399\end{array}$ & $\begin{array}{l}2 \\
6 \\
6 \\
9 \\
4\end{array}$ & $\begin{array}{l}650-674 \\
675-699 \\
700-724 \\
725-749 \\
750-774\end{array}$ & $\begin{array}{r}11 \\
0 \\
1 \\
0 \\
0\end{array}$ \\
\hline
\end{tabular}

Table IV

\begin{tabular}{|c|c|c|c|}
\hline Iepth, kim & $\begin{array}{c}\text { Total energy, } \\
10^{20} \text { ergs }\end{array}$ & Tepth, kn & $\begin{array}{c}\text { Total energy, } \\
10^{20} \text { ergs }\end{array}$ \\
\hline $\begin{array}{r}0-49 \\
50-74 \\
75-99 \\
100-124 \\
125-149\end{array}$ & $\begin{array}{r}3915110,9 \\
485+32,5 \\
178+12,6 \\
25+351,6 \\
10265,5\end{array}$ & $\begin{array}{l}400-424 \\
425-449 \\
450-74 \\
475-499 \\
500-524\end{array}$ & $\begin{array}{r}16515,4 \\
158,5 \\
2488,0 \\
268,1 \\
1046,2\end{array}$ \\
\hline $\begin{array}{l}150-174 \\
175-199 \\
2(00-224 \\
225-249 \\
250-274\end{array}$ & $\begin{array}{r}161739,9 \\
38446,5 \\
50046,6 \\
23893,3 \\
3221,0\end{array}$ & $\begin{array}{l}525-549 \\
550-574 \\
575-599 \\
600-624 \\
625-649\end{array}$ & $\begin{array}{r}588,2 \\
5174,7 \\
1807,0 \\
17480,7 \\
4195,9\end{array}$ \\
\hline $\begin{array}{l}275-299 \\
300-324 \\
325-349 \\
350-374 \\
375-399\end{array}$ & $\begin{array}{r}219,2 \\
1465,4 \\
34+69,5 \\
6992,5 \\
905,2\end{array}$ & $\begin{array}{l}650-674 \\
675-699 \\
700-724 \\
725-749 \\
750-774\end{array}$ & $\begin{array}{c}7280,5 \\
0 \\
109,6 \\
0 \\
0\end{array}$ \\
\hline
\end{tabular}

Total energy: 5,222085. $10^{26}$ ergs. 
$10^{40}$ ergs
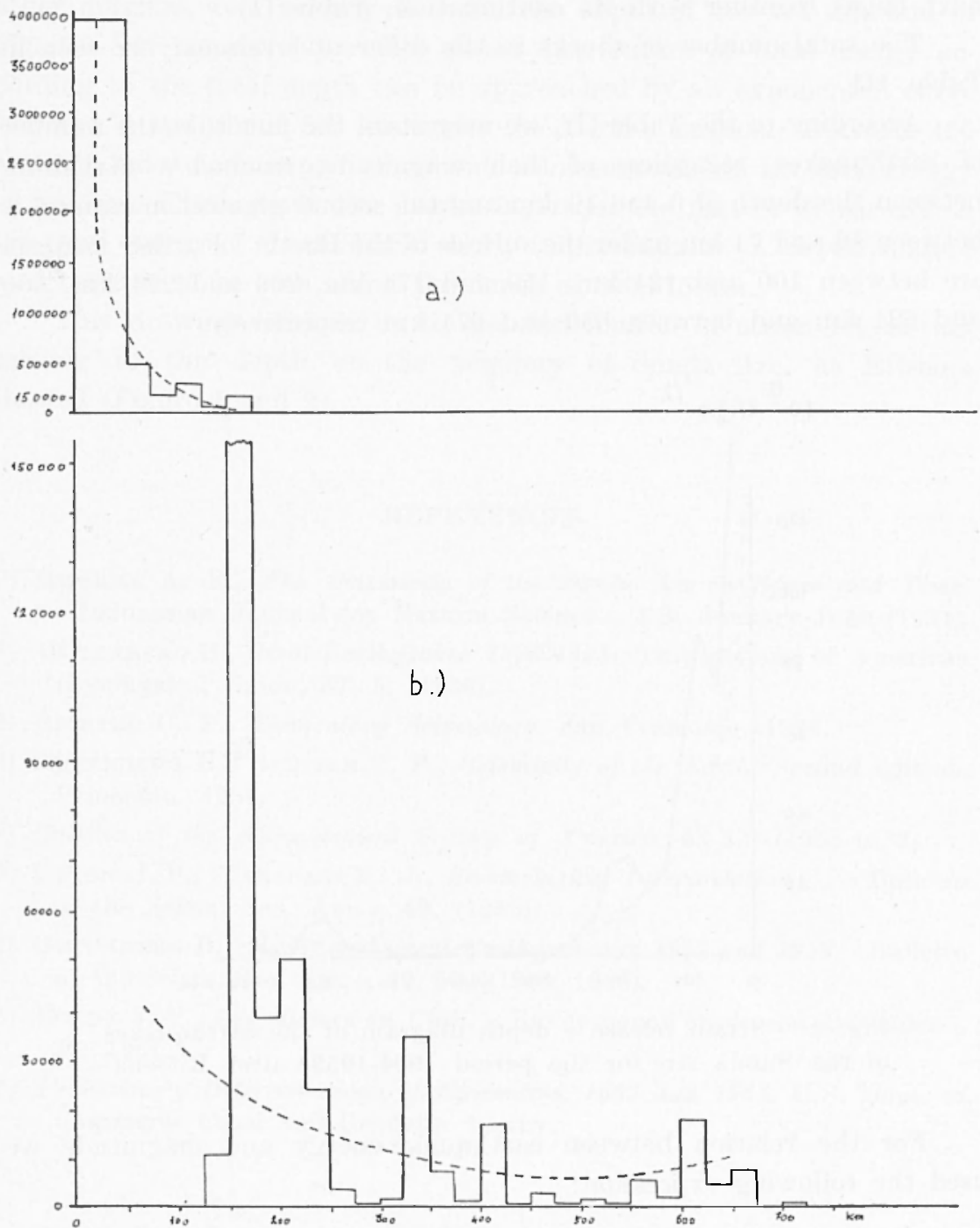

Fig. I - The distribution of eartlunake-energy in accordance with the focal depth, between the period $1896-1963$, all over the world, for shocks between magnitude range of $6,9-8,9$ (according to the present author).

a) between the depth of 0 and $175 \mathrm{~km}$;

b) between the depth of 125 and $750 \mathrm{~km}$. 
The Table I shows the number of the above mentioned earthquakes according to their magnitude and focal depth respectively (see on tha next pages together with its continuation, Table II).

The total number of shocks in the different levels may be seen in Table III.

According to the Table III, we may state the fact that the number of earthquakes, regardless of their magnitude, reached a maximum between the depth of 0 and $49 \mathrm{~km}$ and the second greatest maximum is between 50 and $i t \mathrm{~km}$ under the surface of the Earth. Further maxima are between 100 and $124 \mathrm{~km}, 150$ and $174 \mathrm{~km}, 200$ and $224 \mathrm{~km}, 600$ and $624 \mathrm{~km}$ and between 650 and $674 \mathrm{~km}$ respectively.

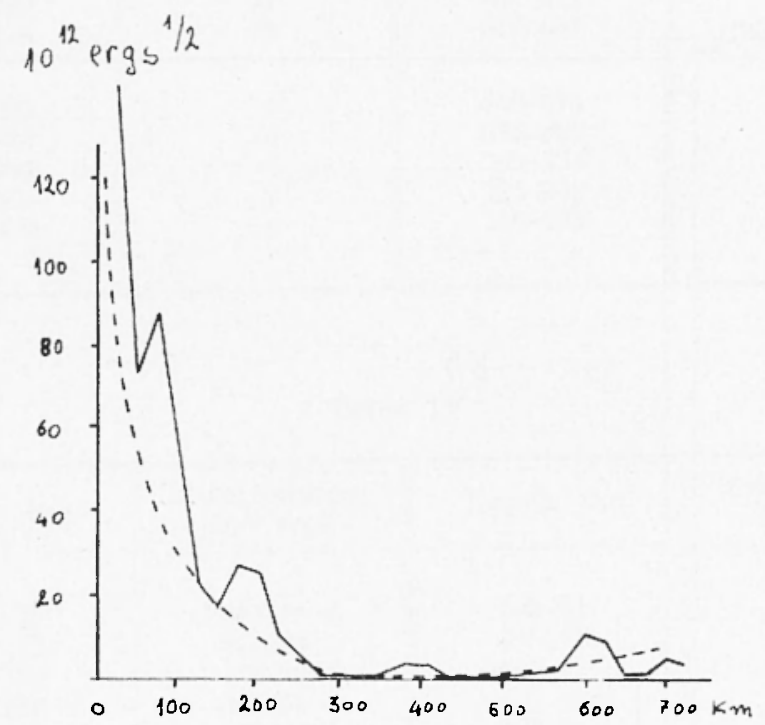

Fig. 2 - Strain release - depth diagram of the earthquakes of the Sunda Are for the period 1904-1953, after Ritsena.

For the relation between earthquake-energy and magnitude we used the following expression:

$$
\log E=11+1,6 M
$$

where $E$ is the energy in ergs and $M$ is the magnitude.

Using this formule, we got for the energy-distribution according to depth, the results of Table IV.

We state the fact that the total energy of shorks as a function of depth reached a maximal height between 0 and $49 \mathrm{~km}$ moler the surface 
and the second greatest maximum could be found immediately under this level, that is between the depth of 50 and $74 \mathrm{~km}$. There are several other maxima, too, namely between the depth of 150-174 $\mathrm{km}$ and of $325-349 \mathrm{~km}$ respectively. The global distribution of total energy according to the focal depth can be approached by an exponential curve between 0 and about $500 \mathrm{~km}$ under the Earth's surface. Between 450 and $550 \mathrm{~km}$ we can experience a wide minimum-zone in the total energy of shocks. Throughout the deeper layers in the mantle of the Earth the total energy of shocks begin slowly to grow again. A newer, smaller maximum is to be seen about the depth of $600-675 \mathrm{~km}$.

This drawing reminds us to the distribution of strain release according to the depth on the territory of Sunda Arc, as Ritsema showed (Figure 1 and 2 ).

\section{REFERENCES}

(1) Ritsema A. R., The Seismicity of the Sunda Arc in Space and Time. "Indonesian Journal for Natural Science ", 1-3, January-June (1954).

${ }^{(2)}$ Gutenberg B., Great Earthquakes 1896-1903. Transactions of American Geophysical Union, 37, 5, (1956).

(3) Riciter C. F., Elementary Seismology. San Francisco, 1958.

(1) Gutenberg B., Riciter C. F., Seismicity of the Earth. Second edition. Princeton, 1954.

(5) Bulletin of the Seismological Society of America. 43-52, (1953-1962).

$\left.{ }^{6}\right)$ Eaton J. P., Takasaki K. J., Seismological Interpretation... "Bulletin of the Seism. Soc. Am. ", 49, (1959).

(7) Gutenberg B., Major and Great Earthqualies of 19:57 and 19:58. "Bulletin of the Seism. Soc. Am. ", 49, 50, :(1959, 1960).

(') Rotin J. P., Les seismes du Chili. "Revue pour l'itude des calamites", 37, 1961 .

(') Preliminary Determinations of Epicentres, 196: and 1963. U.S. Dept. of Commerce Coast and Geodetic Survey. 